\title{
PEMBUATAN ABON IKAN GUNA MEMBANTU EKONOMI KELUARGA DI MASA COVID DI DESA JATISELA KECAMATAN GUNUNGSARI KABUPATEN LOBAR
}

\author{
L.Hendra Maniza1), Sudarta'), Nur'Aini'1) \\ ${ }^{1)}$ Program studi Administrasi Bisnis, Fakultas IImu Sosial Dan IImu Politik, Universitas Muhammadiyah Mataram, \\ Mataram, NTB, Indonesia \\ Corresponding author: Nur'aini \\ E-mail : aininingrum77@gmail.com
}

Diterima 26 Februari 2021, Direvisi 05 Mei 2021, Disetujui 08 Mei 2021

\begin{abstract}
ABSTRAK
Tujuan pengabdian kepada masyarakat ini adalah untuk membantu anggota UKM yang ada di desa jatisela kecamatan gunungsari dalam memasarkan produk nya secara online dan offline, memiliki kemampuan berinovasi dengan bahan baku yang ada di lingkungan sendiri, Bisa menjadi sumber mata pencaharian sehingga dapat membantu kebutuhan rumah tangga di masa sulit saat ini seperti pandemi.pengabdian ini dilakukan dengan metode penyuluhan,pelatihan dan evaluasi hasil yang telah dicapai,dimana mitra yang kami undang adalah yang ingin menambah pengahasilan dan yg memiliki usaha namun tak berkembang, edukasi yang diberikan dengan sosialisasi peragaan pembuatan langsung dengan 13 orang mitra dengan di ketuai oleh salah seorang anggota UKM.tiga metode yang telah tim pengabdian lakukan diantaranya mengevaluasi hasil dari mitra sejauh mana perkembangan usaha pelatihan yang diberikan pihak pengabdian dalam memasarkan usaha abon dan kemampuan dalam pembuatan abon dengan protocol kesehatan di masa covid seperti sekarang ini.
\end{abstract}

Kata kunci: pembuatan abon; membantu ekonomi keluarga; dimasa pandemi

\begin{abstract}
The purpose of this community service is to help UKM members in the village of Jatisela, Gunungsari sub-district in marketing their products online and offline, have the ability to innovate with raw materials in their own environment, can be a source of livelihood so they can help household needs in Today's difficult times are like a pandemic. This service is carried out by means of counseling, training and evaluation of the results that have been achieved, where the partners we invite are those who want to increase their income and who have businesses but are not developing, education is provided with the socialization of direct manufacturing demonstrations with 13 a partner chaired by a member of the UKM. The three methods that the service team have done include evaluating the results of partners, the extent to which the development of the training efforts provided by the service party in marketing shredded businesses and the ability to make shredded shredded with health protocols during the Covid period such as rti now.
\end{abstract}

Keywords: shredded making; help the family economy; during the pandemic

\section{PENDAHULUAN}

Berada dalam kondisi pandemi saat ini, banyak produk usaha yang gagal terjual di pasar yang di sebabkan oleh tidak adanya kemampuan masyarakat dalam membeli terutama di masa wabah COVID-19, selain itu keterbatasan modal ikut menjadi faktor penyebab tidak mampu nya usaha kecil menengah ini menjadi idola di pasar walaupun sesungguhnya produk ini merupakan selera masyarakat khususnya di Lombok umumnya di Indonesia

Di sisi lain, wabah COVID- 19 ikut
meruntuhkan sendi-sendi perekonomian keluarga dimana banyak para pekerja yang di rumahkan. namun para usaha kecil tidak berhenti berinovasi dan berkereasi. Di Desa
Jatisela Kecamatan Gunungsari kabupaten Lombok Barat, mitra Usaha Kecil Menengah membuka peluang usaha abon dengan bahan dasar ikan laut seperti ikan guling-guling, tongkol, layah, dan langoan, yang biasanya lebih murah harganya dibanding ikan yang lainnya, namun tidak mengurangi cita rasa dan kualitas abon ikan tersebut, Abon merupakan salah satu jenis makanan berbahan dasar dari daging ikan, Abon biasanya dikonsumsi untuk lauk pauk dengan menaburkannya di atas nasi atau sebagai cemilian. Abon ikan aroma dan rasanya tidak kalah dengan abon daging yang biasa ada di pasar tradisional atau pasar modern.

Peluang usaha abon ikan di saat COVID ini cukup menjanjikan sehingga bisa membantu 
memenuhi kebutuhan ekonomi kelurga dan bisa membantu membuka peluang usaha dalam mengembangkan usaha abon ikan dengan istiqomah.

Sebagaimana diketahui Pemerintah Indonesia akhirnya resmi menetapkan ikan jadi komoditas terkini yang masuk sebagai bahan pokok dan barang penting melalui Peraturan Presiden No 71 Tahun 2015 tentang Penetapan dan Penyimpanan Barang Kebutuhan Pokok dan Barang Penting.

Tingginya protein pada abon ikan berfungsi untuk pertumbuhan dan pembentukan massa otot.Abon memiliki kandungan zat besi yang tinggi dan hal ini berfungsi untuk memperlancar peredaran darah dan mempercepat pembentukan sel darah merah. Apabila kedua hal ini dapat berfungsi normal seperti semestinya, maka badan kita akan tetap sehat dan meminimalisir risiko anemia pula. Selain itu, adanya kandungan lemak pada abon juga berfungsi untuk membuat kita merasa kenyang dalam waktu yang lama.

Ikan adalah sumber protein yang tinggi dan sebagai kebutuhan pokok, ikan tidak tahan lama jika hanya untuk di konsumsi biasa, namun dengan adanya kreasi dari mitra usaha kecil menengah yang lebih inovatif maka proses ikan menjadi abon yang bebas pengawet serta tahan lama, menyebabkan makanan ini laku pesat di masa COVID.

Maka dari itu pelatihan dan keterampilan proses pembuatan abon ikan baik dari segi penyajian dan kemasan pembuatan abon ikan ini membantu para ibu ibu dan warga menambah penghasilan tambahan keluarga mereka.

Adapun tujuan dari pengabdian ini adalah : 1. Untuk Anggota UMKM khususnya dan masyarakat pada umumnya memiliki skill dalam memasarkan produk secara online. 2 . Memiliki kemampuan berinovasi dengan bahan baku yang ada di lingkungan mereka sendiri. 3 . Bisa menjadi sumber mata pencaharian antar teman atau menjual dari rumah ke rumah sambil mengajarkan pada orang lain agar bisa membuka usaha peluang baru dalam pelatihan pembuatan abon ikan yang di inginkan.4. mengisi waktu luang, jika ada kesibukan lain jadi waktunya bisa bermanfaat bagi diri dan orang lain dengan mengajarkannya kembali.

Dari simpulan di atas bisa di ketahui 4 tujuan dari pelatihan pengabdian kepada masyarakat ini, yang mana bertujuan agar lebih berkesenambungan agar kegiatan untuk memperbaiki tarap kehidupan para UKM dan masyarakat lebih ter arah dan memiliki market yang tepat.

\section{METODE}

Metode yang digunakan dalam kegiatan ini yaitu melalui penyuluhan,yang di adakan di minggu pertama hari minggu tanggal, 10 januari 2021, berupa penyuluhan dan sosialisasi untuk mengikuti sesi berikutnya. Tanggal 17 januari di rumah ketua kelompok salah satu dari mitra di hadiri oleh 12 orang, dan pelatihan di adakan jam 15.00 wita. kepada usaha kecil yang ada di sekitar untuk bergabung dalam usaha pembuatan abon, karna di masa sulit seperti Pandemi-covid 19 sekarang ini pengolahan abon ikan cukup mendapat peminat, di karenakan makanan jenis abon ini awet, mudah dibuat serta orang tidak ragu untuk membelinya, selain harganya cukup murah dan menghemat waktu karena tidak harus keluar rumah setiap hari untuk berbelanja membeli ikan buat keluarga, karena di masa sulit seperti saat ini sangatlah berhati hati orang untuk keluar rumah walau hanya untuk belanja dikarenakan risih dengan kondisi jaga jarak, cuci tangan dan dengan menggunakan masker maka untuk kebutuhan pasti akan memilih yang praktis dan ekonomis.

Pelaksanaan kegiatan pengabdian melalui beberapa tahap diantaranya sebagai berikut;

1. Penyuluhan

Setiap Mitra Usaha Kecil yang tergabung dalam Kumpulan Anggota koperasi Kecamatan Gunungsari Kabupaten Lombok Barat yang ingin menambah penghasilan ekonomi keluarga di masa pandemik atau di masa new normal, akan mendapatkan informasi tentang cara membuatan abon ikan dari proses pengolahan dan pembukusan hingga pemasarannya. Namun bagi yang belum tergabung dalam anggota koperasi dan memiliki usaha kecil yang ingin berkreasi dalam keahlian yang di milikinya, tetap akan di fasilitasi untuk memperoleh informasi dan teknik cara pembuatan abon ikan. Dalam penyuluhan yang di adakan pihak pengabdian kami tidak memungut biaya, selama mitra memiliki ide kreasi yang membuat kelompok usaha berkembang.

2. Pelatihan

Setiap mitra di latih bagaimana memilih dalam membeli bahan baku ikan segar hingga menghasilkan abon yang berkwalitas baik. Dan setiap Mitra dalam kegiatan di kantor desa diharapkan ikut terlibat agar mendapatkan pengetahuan dan informasi yang di dapat demi memajukkan ekonomi keluarga dan pendapatan desa jatisela, sehingga bisa saling tukar sumber daya yang ada di masing masing peserta Pelatihan. 
Penyuluhan dan pelatihan Mitra dapat dilaksanakan 1 (satu) minggu sekali di kantor desa atau di rumah ketua kelompok usaha kecil. Pelaksanaannya setiap sore sesudah sholat asar. Waktu sesuai kesepakatan dari para mitra usaha.

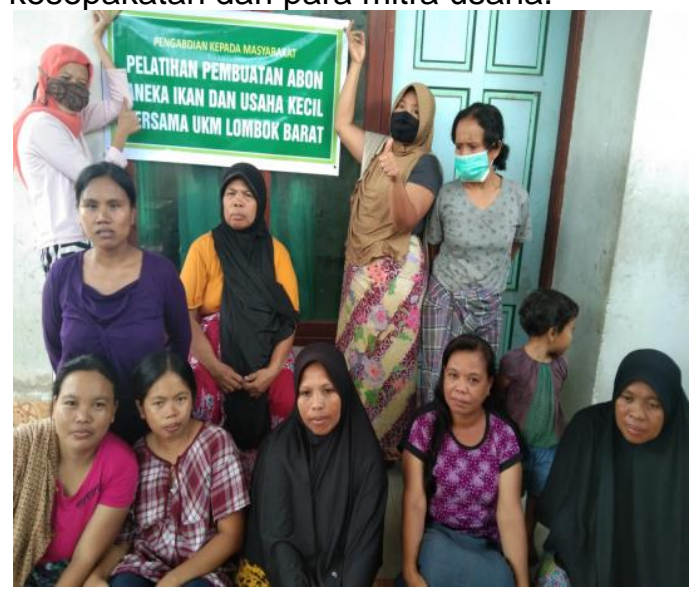

Gambar 1: Sesi foto saat akan mendengarkan materi pelatihan

Cara pembuatan, bahan dan alat yang di gunakan saat memberikan pelatihan antara lain :

a. Memilih ikan yang segar dan membeli bahan seperti cabe, kunyit, laos, jahe, terasi, garam, penyedap, bawang putih, bawang merah, gula pasir dan minyak kelapa

b. Ikan di bersihkan isi dalamnya hingga ikan tidak mengeluarkan darah.

c. Ikan di masak pake garam secukupnya.

d. Tunggu dingin 15 menit, ikan di bersihkan kembali tulang ikan di buang, warna coklat ikan dan kepala ikan, (tidak diambil) kulit ikan dibuang hanya daging putih ikan yang diambil

e. Ikan ditumbuk dan dicampur dengan bumbu yang sudah dihaluskan, lalu di goreng

f. Lalu ikan dipres/penekan dengan menggunakan alat pres abon agar minyak tersaring dan tidak mengandung banyak minyak pada olahan abon ikan tersebut.

g. Lalu dikemas.

h. Dipasarkan siap dijual

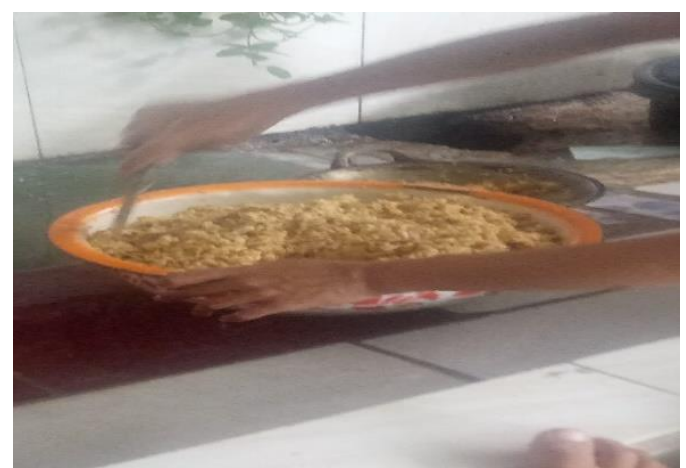

Gambar 2. Tahap penolahan ikan

\section{HASIL DAN PEMBAHASAN}

Dengan munculnya bencana virus corona yang mendunia ini, menimbulkan krisis ekonomi secara menyeluruh. Karena virus ini memaksa masyarakat untuk menjaga diri dengan diam dirumah dan melakukan karantina secara mandiri untuk memutus rantai penyebaran COVID-19. Selama masa karantina, membuat banyak sector mati suri misalnya sektor pariwisata, dan sektor pendidikan, hal ini menyebabkan menurunya pendapatan sebagian besar masyarakat. Banyak yang kesulitan perekonomian karena matinya mata pencaharian mereka.

Oleh karena itu pelatihan dilakukan dengan mengundang ibu-ibu, anak remaja yang putus sekolah serta ibu ibu yang menjadi anggota mitra usaha mandiri di Desa Jatisela Kecamatan Gunungsari, Kabupaten Lombok Barat yang di koordinasi oleh ketua kelompok usaha kecil menengah. Mitra menyediakan tempat untuk pelatihan pembuatan abon ikan ini dan kami beserta tim memberikan arahan cara pembuatan dengan prtokol kesehatan.

Desa Jatisela terdiri dari 5 (lima) Dusun yaitu Dusun Johar Pelita, Dusun Jati Ireng, Dusun Griya Asri, Dusun Ireng Daye dan Dusun Ireng Lauq. Dan memiliki suhu udara masih alami dan dekat dengan pantai, serta di kelilingi oleh sungai yang cukup luas, sehingga perajin memulai usaha abon ini cukup dekat jaraknya membeli ikan langsung dari perahu nelayan, jadi dapat dipastikan ikan yang di gunakan sudah masih segar.

Adapun yang menjadi masalah di pihak mitra adalah sebagai berikut:

1. Tidak memiliki modal yang kuat untuk keberlanjutan usaha, dimana ketika ada permintaan dari pembeli dalam skala besar para pelaku perajin rumahan abon ikan tidak mampu memenuhi permintaan.

2. Kedua Belum memiliki analisis pasar yang tepat sehingga penjualan masih terbatas pada tetangga dan teman dekat (tidak memiliki segmen pasar)

3. Cara penjualan masih konvional, Maksudnya adalah dari bentuk dan tampilan 
kemasan masih sederhana dan cara penjualan yang skalanya kecil,

4. Kurangnya pelatihan yang diadakan oleh ketua kelompok Usaha Kecil sehingga setiap usaha yang di tekuni oleh UKM tidak bisa berjalan dengan sukses dan berkesinambungan/Istigomah.

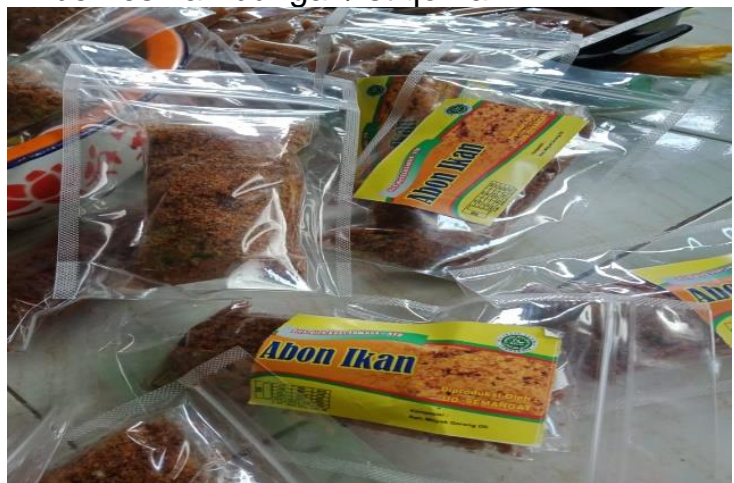

Gambar 3. Tahap pengemasan

Hasil capaian Program pengabdian yang sudah dilaksanakan ini, diharapkan dapat mengetahui cara membuka peluang usaha di era COVID saat ini dengan memanfaatkan ikan yang murah menjadi produksi yang dapat diterima pasar dengan cara:

1. Membantu Mitra usaha Kecil (UKM) abon ikan agar bisa menjual secara luas mimiliki segmen pasar atau marketplace bisa menjual secara online atau offline.

2. Meningkatkan pengetahuan atau mengedukasi ibu ibu yang tidak memiliki penghasilan sehingga bisa membantu ekonomi keluarga lebih meningkat di Desa jatisela kecamatan Gunungsari.

\section{SIMPULAN DAN SARAN Simpulan}

Melalui kegiatan pengabdian kepada masyarakat ini dapat disimpulkan sebagai berikut : 1. Anggota UMKM khususnya dan masyarakat pada umumnya memiliki skill untuk memasarkan produk secara online. 2. Memiliki kemampuan berinovasi dengan bahan baku yang ada di lingkungan mereka sendiri. 3. Bisa menjadi sumber mata pencaharian antar teman atau menjual dari rumah ke rumah sambil mengajarkan pada orang lain agar bisa membuka usaha peluang baru dalam pelatihan pembuatan abon ikan yang di inginkan.4. mengisi waktu luang, jika ada kesibukan lain jadi waktunya bisa bermanfaat bagi diri dan orang lain dengan mengajarkannya kembali.

Dari simpulan di atas bisa di ketahui 4 tujuan dari pelatihan pengabdian kepada masyarakat ini, yang mana bertujuan agar lebih berkesenambungan agar kegiatan untuk memperbaiki tarap kehidupan para UKM dan masyarakat lebih ter arah dan memiliki market yang tepat.

\section{Saran}

Mengingat peserta yang mendapat kesempatan mengikuti pelatihan ini terbatas karena kondisi pandemik sekarang ini, maka perlu adanya upaya untuk melanjutkan kegiatan pelatihan serta perlu adanya pembimbing secara berkelanjutan untuk mendapatkan hasil yang optimal.

Perlu pendampingan dan pertemuan secara formil atau non formil dan berkelanjutan mengenai usaha pembuatan abon ikan untuk usaha masyarakat yang ingin menambah penghasilan ekonomi keluarga dalam masa sulit seperti sekarang ini yaitu masa pandemic COVID-19 saat ini.

\section{UCAPAN TERIMA KASIH}

Kami selaku tim pengabdian mengucapkan terimakasih ke Lembaga Pengabdian Pada Masyarakat (LPPM) Universitas Muhammadiyah Mataram yang telah mendanai kegiatan pengabdian ini melalui hibah pengabdian Universitas Muhammadiyah Mataram. Sehingga kegiatan Pembuatan abon ikan bisa terlaksana dengan baik. sehingga kegiatan pengabdian ini dapat terlaksana dengan baik.

\section{DAFTAR RUJUKAN}

Andreas. (2011). Manajemen Keuangan UKM. Graha IImu.

D Nurani, A Amar, M Muhami, S. M. (2011). Modul Pembelajaran Bidang Pangan: Pengolahan Hasil Pertanian, Perikanan, Dan Kelautan. Kementrian Agama Republik Indonesi.

Handanari, T., Yuwono, T., Paulus, T. F., Azizah, N., \& Ramadhani, A. P. (2016). Rekomendasi Teknologi dan Perikanan. Badan Penelitian dan Pengembangan Kelautan dan Perikanan Kementrian Kelautan dan Perikanan.

Kotler, P., \& Keller, K. L. (2009). Manajemen pemasaran Jilid 1. In Jakarta.

Manfaat, R. (2021). 5 Manfaat Abon Ikan Untuk Kesehatan. https://manfaat.co.id/manfaatabon-ikan

Winarno, F. . (2008). Teknobiologi Pangan. MBrio Biotekinkindo. Baranangsiang-Bogor 